\title{
Neighbourhood open spaces for social cohesion
}

\author{
Rukhsana Badar ${ }^{1}$ and Sarika Bahadure ${ }^{2}$ \\ ${ }^{1}$ Insitute of Design Education and Architecture Studies, Hudkeshwar, Outer Ring Road, Nagpur, Maharashtra 440037 \\ ${ }^{2}$ Department of Architecture and Planning,VNIT, South Ambazari Road, Nagpur, Maharashtra, India -440010
}

\begin{abstract}
The global cities of the world are witnessing a visible disconnection of everyday life. In India the Smart City guidelines acknowledge the need to counter the growing social detachment and intolerance by encouraging interactions. They go further in identifying that preserving and creating of open spaces must be a key feature of comprehensive urban development. Most social relations are cemented within open spaces at the neighbourhood level. Previous studies examine the association between the attributes of neighbourhood open spaces and social activity but neglect to view the issue comprehensively. The present study turns to Lefebvre's Unitary Theory which states that open space is a result of three forces; 1 ) perceived space which is the physical dimension and material quality identifiable by the senses; 2) conceived space created by planners and other agents as plans and documents; and 3) lived space which is shaped by the values attached and images generated through user experience. For open space conducive to social interactions these three aspects must work in tandem. With this consideration a framework of criteria and indicators is developed and used to measure and compare the open spaces in select neighbourhoods in Europe and India. The investigation thus reveals differences in all three aspects of neighbourhood spaces. It also reveals a discrepancy between the planning standards formulated and employed by the city authorities in providing the spaces and the actual needs of the community. The research aims to address this gap. The study of the Indian cases lays foundation for the use of the framework to measure open spaces in association with social cohesion and thereby contribute to the enhancement of the social infrastructure of the City.
\end{abstract}

\section{Introduction}

Forrest and Kearn [1] acknowledge that the rapid and unplanned urbanization during the first half of the twentieth century produced social order in which the traditional ties of community were replaced by anonymity, individualism and competition. At the same time the literature of the late 1900s was filled with laments over the loss of convivial public spaces. Salama and Ghraib [2] emphasise that traditionally cities or urban spaces were able to evolve over a period of time to accommodate a diversity of activities and provide a variety of experiences. Modern cities face the challenge of providing these qualities to accommodate the sudden increase in social diversity. Legeby and Marcus [3] support the idea that sharing public space and everyday activities is a crucial prerequisite for promoting integration and fostering tolerance in society [4,]. Chen et al [5] identify that the important factors effecting the use of an open space are its attributes, users attributes and the distance between the space and the users. Though these links have been established there is still a gap put forward by Constant [6] who observes the growing discrepancy between the standards applied in allocating urban space and the real needs of the community.

In a learning of social cohesion, it is useful to consider the concept of 'neighborhood' as it is defined in urban sociology as a starting point in a discussion of social relations within a spatially bounded area [7]. The study thus aims to identify a process that can aid in the designing and planning of neighborhood spaces for a vibrant social life and increased social interaction.

The study is divided into three parts. The first part is an understanding of neighborhood open spaces and their relationship with social cohesion. A learning of the categorization of neighborhood open spaces is made. The research then moves towards an exploration of selected spatial theories that relate neighborhood open spaces to social cohesion. This is undertaken in order to reveal criteria for study of the said spaces. The second part uses a case study method to formulate indicators to measure neighborhood open spaces for social cohesion. The third part of the study compares the neighborhood open spaces in Indian context with relation to social cohesion. A framework is thereby developed for the study.

\section{Neighbourhood Open Spaces}

Open space is a broad term that can be used to describe all land that does not contain buildings and structures [8]. Though a major part of the neighborhood consists of residential area which is supported by commercial, institutional and other built-up land uses, an important component consists of open space. Chen et al [5] establish the benefits of the neighborhood open space in providing opportunities for children's play, passive and active recreation for all age groups, education, improving physical health, increased economic value, crop production and for community and cultural activities. Without a space conducive to social life, community relations cannot prosper and grow [9].

\subsection{Categorization:}

The Urban and Regional Development Plans Formulation and Implementation (URDPFI) Guidelines [10] categorizes urban open spaces into three types: i) Recreational space; ii) Organized green; iii) Other common open spaces (such as vacant lands, open spaces including flood plains, forest cover, etc.). It establishes a hierarchy of spaces for different levels of city use including neighborhood. This physical categorization fails to integrate the social activities that are to be performed in these spaces. Stanley \& Stark [11] delineate seven major 
types of open space according to form and function: (1) food production areas; (2) parks and gardens; (3) recreational space; (4) plazas; (5) streets; (6) transport facilities; and (7) incidental space. Each type is further categorized by a spatial scale from city-wide to intermediate (neighborhood level) to individual buildings. The spaces are also differentiated into green spaces (which contain vegetated land, water or geological feature) and grey spaces (which are civic-oriented). The present study focuses on the intermediate (neighborhood) space.

\subsection{Social Cohesion:}

Forrest \& Kearns [1] affirm that social cohesion is the need for a shared sense of morality and common purpose; a social order that specifies the level of social interaction within communities or families; and a sense of belonging to place. For neighbourhood, it is the concept of 'nearness' both as physical and social proximity that is central to social cohesion. The spatial layout of a neighbourhood can influence physical proximity which may in turn affect the relationship between potential contacts in a social network [12]. Gri [13] notes that neighbourhood public spaces play a crucial role in facilitating community interaction through which experiences are shared and identities and values of different cultures are celebrated.

\subsection{Measurement:}

The selected theories that aim to decipher the complex relationship between space and society and provide a framework for the analysis of neighbourhood public spaces and social activities are i) Structuration theory of Anthony Giddens[14]; ii)Space Syntax Theory of Bill Hillier and Julian Henson [15]; and iii) Unitary Theory of Henri Lefebvre [16]. In the Structuration Theory Giddens uses the daily route followed by people as a means of analyzing urban open space. He neglects the perception of the users and the claims by governing bodies. The Syntax Theory relates space formation with daily use and to cognitive response by the people but fails to address the limitations imposed by governance and the possibilities imagined by planners.

The Unitary Theory is able to unite the three forces responsible for the formation of open space, the physical dimensions of the space, the mental picture created by planners and regulators and the meaning given to the space by its users. It thus forms the basis for the study of neighbourhood open spaces for social cohesion.

\subsection{Unitary Theory of Production}

In his book 'The Production of Space', Lefebvre [16] finds that presently public spaces are mass produced like a product. People's activities and behavior within these public open spaces are regulated through political and economic forces. According to Weinert [17] real social change can only be brought about if people are given the power over space so that they can create, appropriate and play with it. Lefebvre suggests the Unitary Theory, seeking to unify the three fields of space:

\subsubsection{Perceived Space (First Space):}

It is associated with spatial practise of a society which through time and dynamic interaction, produces space and appropriates it. This is revealed by close relationship between urban reality and daily life.

\subsubsection{Conceived Space (Second Space):}

It is the space imagined and created by scientists, planners, urbanists, technocratic sub-dividers and social engineers. Weinert [17] refers to it as the administrating space that supports the modes of governance by the state. It presently dominates the production of open space.

\subsubsection{Lived Space (Third Space):}

It is the social space where people live their everyday lives and interact. It may be expressed in terms of how people interpret the space and give "meaning" to it, and how such meaning helps develop a sense of community or place[18].Table 1 lists the criteria for each space based on the understanding.

Table 1 Understanding of Criteria for Production Of Open Space Adapted From [16]

\begin{tabular}{|l|l|l|}
\hline \multicolumn{2}{|c|}{ Space Adapted From [16] } \\
\hline \multirow{4}{*}{ PERCEIVED } & CRITERIA & UNDERSTANDING \\
\cline { 2 - 3 } & $\begin{array}{l}\text { Daily } \\
\text { Routine }\end{array}$ & $\begin{array}{l}\text { Activities that conform with } \\
\text { official representation of space }\end{array}$ \\
\cline { 2 - 3 } & $\begin{array}{l}\text { Urban } \\
\text { Reality }\end{array}$ & $\begin{array}{l}\text { Physical dimensions \& } \\
\text { materials }\end{array}$ \\
\hline \multirow{4}{*}{ CONCEIVED } & Concepts & $\begin{array}{l}\text { Intellectualized official } \\
\text { conception of urban areas for } \\
\text { administrative and property } \\
\text { development }\end{array}$ \\
\cline { 2 - 3 } LIVED & Codes & $\begin{array}{l}\text { Rules of how, when, where and } \\
\text { who can use the space }\end{array}$ \\
\hline & Experiences & $\begin{array}{l}\text { Meanings and values attached } \\
\text { to the space by the user }\end{array}$ \\
\cline { 2 - 3 } & $\begin{array}{l}\text { Images \& } \\
\text { Symbols }\end{array}$ & Artistic vision of the space \\
\hline
\end{tabular}

\subsection{Indicators and Tools for Measurement}

The formulated criteria are applied in the study of neighbourhood open spaces with a view of evaluating social cohesion. Two works are studied to appreciate the indicators and methods used for spatial analysis under the triad propounded by the Unitary Theory: i) a post occupancy evaluation of the public open spaces of MediaCityUK., U.K. by Gorska \& Materna [19] and ii) an examination of open spaces of Jattavagen, Norway by Griffith [20].

\subsubsection{Mediacityuk, Manchester, United Kingdom:}

Located in the Salford Quays, it is a former abandoned dockland which is part of a significant urban regeneration program started in 1985 under the Salford Quays Development Plan [19]. The provisioned open spaces consists of i) the Piazza; ii) the terraced Waterfront Area; and iii) the Park (Fig. 1).

\subsubsection{Jattavagen, Stavanger, Norway:}

Another abandoned docking area and construction site, it was ear marked for redevelopment as a new urban district with commercial and residential space. The latest masterplan for the area is a result of merging three different winner-entries in the international competition held in the year 2000. The considered public spaces are: i) Central park; ii) Central Plaza; iii) Axial Promenade; iv) Waterfront Park (Fig. 1). The listed indicators from the two chosen case studies are adapted in a framework developed to study open spaces in Indian neighbourhoods. 

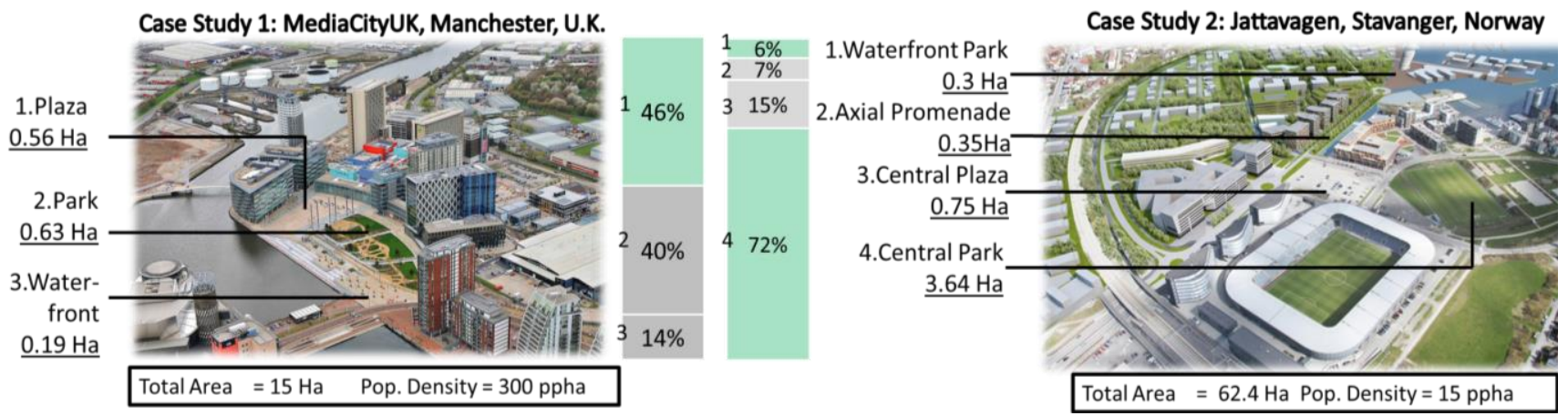

Fig. 1 Open Spaces in the chosen European neighborhoods

Table 2 Indicators, methods/ tools used to study Open Spaces in MediaCityUK and Jattavagen using Unitary Theory

\begin{tabular}{|c|c|c|c|c|c|}
\hline \multirow{2}{*}{ 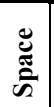 } & \multirow[t]{2}{*}{ Criteria } & \multicolumn{2}{|c|}{ MediaCityUK, UK } & \multicolumn{2}{|r|}{ Jattavagen, Norway } \\
\hline & & Indicator & Method \& Tool & Indicator & Method \& Tool \\
\hline \multirow{10}{*}{ 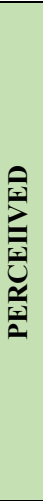 } & \multirow[t]{3}{*}{ Urban Reality } & & & Building Height & \multirow[t]{2}{*}{ Typo morphological Analysis } \\
\hline & & & & Building Type & \\
\hline & & & & Surface materials & Land cover analysis \\
\hline & \multirow[t]{7}{*}{ Daily Routine } & $\begin{array}{l}\text { Intended Use - activity } \\
\text { i) Sedentary ii)Walking } \\
\text { iii)Vigorous }\end{array}$ & $\begin{array}{l}\text { System for Observing Plan } \\
\text { and Recreation in } \\
\text { Communities (SOPARC) }\end{array}$ & Intended Use & $\begin{array}{l}\text { Landscape features analysis- listing of site } \\
\text { amenities }\end{array}$ \\
\hline & & Purpose of visit & \multirow[t]{6}{*}{ Intercept survey } & \multirow[t]{6}{*}{ Connectivity } & \multirow{6}{*}{$\begin{array}{l}\text { Accessibility analysis }- \text { i)Vehicular access } \\
\text { points ii)Pedestrian access points }\end{array}$} \\
\hline & & $\begin{array}{l}\text { Main purpose of using } \\
\text { space }\end{array}$ & & & \\
\hline & & Relation to $\mathrm{NH}$ & & & \\
\hline & & Frequency of visits & & & \\
\hline & & Mode of transport & & & \\
\hline & & Popularity & & & \\
\hline \multirow{2}{*}{ 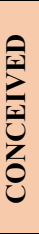 } & Concepts & Planner's Ideas & Professional Interviews & $\begin{array}{l}\text { Competition } \\
\text { Document }\end{array}$ & $\begin{array}{l}\text { Document analysis: i) Urban Development } \\
\text { in Stavanger: An Open Norwegian City } \\
\text { Planning Competition } 2000\end{array}$ \\
\hline & Codes & Plans & $\begin{array}{l}\text { Document analysis: Local } \\
\text { Zoning plans }\end{array}$ & Plan & $\begin{array}{l}\text { Document analysis: i) Site and Landscape } \\
\text { Analysis (Department of Culture and City } \\
\text { Development (DCUD), 1999; ii) Municipal } \\
\text { DP (DCUD), 2001 }\end{array}$ \\
\hline \multirow{5}{*}{$\sum^{2}$} & \multirow[t]{4}{*}{ Experiences } & $\begin{array}{l}\text { Gehl's } 12 \text { quality } \\
\text { criteria }\end{array}$ & On-site observation & Social Demographics & Survey \\
\hline & & Emotion experienced & \multirow{3}{*}{$\begin{array}{l}\text { Perception study- } \\
\text { Questionnaire survey of } \\
\text { users }\end{array}$} & $\begin{array}{l}\text { Architectural Features } \\
\text { of Home }\end{array}$ & \\
\hline & & Level of satisfaction & & Transit Modality & Behaviour Observations \\
\hline & & \begin{tabular}{|l|} 
Willingness to \\
participate in design \\
process
\end{tabular} & & NH Perception & Qualitative interviews \\
\hline & Images \& Symbols & & & Art & Artist's illustrations in DUCD (2001) \\
\hline
\end{tabular}

\section{Indian Neighbourhood Open Spaces}

Three Indian neighbourhoods are selected for comparison using the developed framework. The first, Jethabhai ni Pol $[\mathrm{NH}(\mathrm{A})]$ is a historic area within the city of Ahmedabad where open space has been perceived through a long period of time since the middle ages. The other two selected neighbourhoods $[\mathrm{NH}(\mathrm{B})$ and $\mathrm{NH}(\mathrm{C})]$ are a part of Aranya Low Cost Housing in Indore designed by Architect B.V.Doshi based on his study of traditional settlements of the subcontinent [21].

The Unitary Theory is used to create a complete picture of how spaces are conceived by the mental forces of planners and institutions, perceived through the spatial practise of the users and lived through everyday experiences. By comparing the neighbourhoods the study intends to weigh the difference in production of the open spaces and its impact on social cohesion.

\subsection{Jethabahi Ni Pol, Ahmedabad [NH(A)]}

A pol is a residential neighbourhood with well-defined boundaries [22]. The boundaries defined the area of jurisdiction, binding the families together under set rules and regulations and thereby creating a sense of belongingness among its inhabitants. The common structure of the pol consists of a gated community of densely packed row houses looking inward onto narrow winding streets that usually lead to a dead end. The back of the houses on the outer edges form a blank wall onto the exterior. The neighbourhood open spaces can be hierarchized according to their openness to the rest of neighbourhood into: i) The outer chowk $(\mathrm{O})$; ii) the 
street space (P); and iii) the inner chowk (Q) (Error! Reference source not found.).

\subsection{Aranya Low Cost Housing, Vijay Nagar, Indore $[\mathrm{NH}(\mathrm{B}) \& \mathrm{NH}(\mathrm{C})]$}

In an attempt to address the problem of acute housing shortage, the Indore Development Authority and the Housing and Urban Development Corporation commissioned Aranya in 1981[21]. The Vastu Shilpa Foundation for Studies and Research in Environment Design under architect B.V. Doshi was entrusted with the task. The present research separates

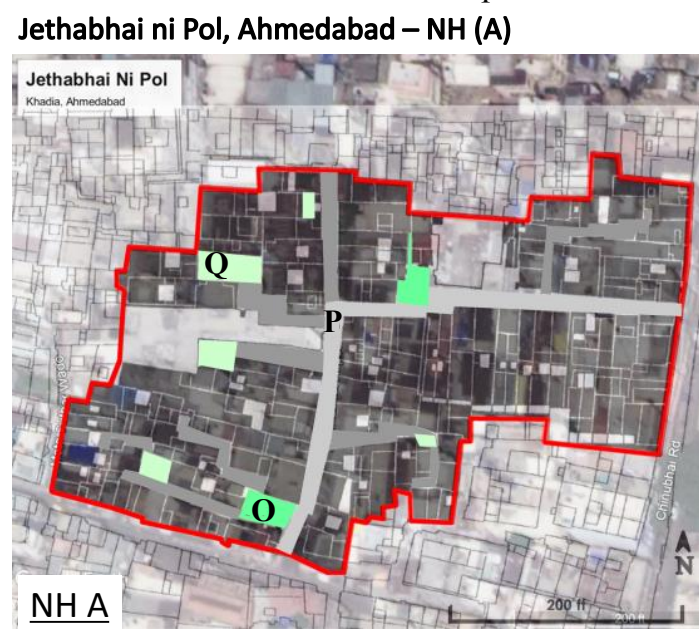

$\mid$\begin{tabular}{l|l|r|}
\hline $\begin{array}{l}\text { Neighborhood } \\
\text { Open Spaces NOS }\end{array}$ & $\begin{array}{l}\text { Area } \\
\text { (sqm. })\end{array}$ \\
\hline \multicolumn{2}{|l|}{ NH A } \\
\hline O & Outer Chowk & 87 \\
\hline P & Street & 295 \\
\hline Q & Inner Chowk & 47 \\
\hline NH B \\
\hline R & Street & 1019 \\
\hline S & Chowk & 323 \\
\hline T & Cluster space & 98 \\
\hline NH C \\
\hline X & Street & 875 \\
\hline
\end{tabular}

two neighbourhoods within the housing settlement for the purpose of study. The neighbourhood, NH(B) consists of the first demonstration houses that were built by the Vastu Shilpa Foundation. The second neighbourhood, NH(C) consists of a designed housing scheme along one of the large streets that runs through the site. In $\mathrm{NH}(\mathrm{B})$, the neighbourhood open spaces include i) street (R); ii) chowks (S) formed on street $\mathrm{R}$; iii) courtyard at cluster level (T); and in $\mathrm{NH}(\mathrm{C})$ the open space is restricted to the street (X) (Error! Reference source not found.).

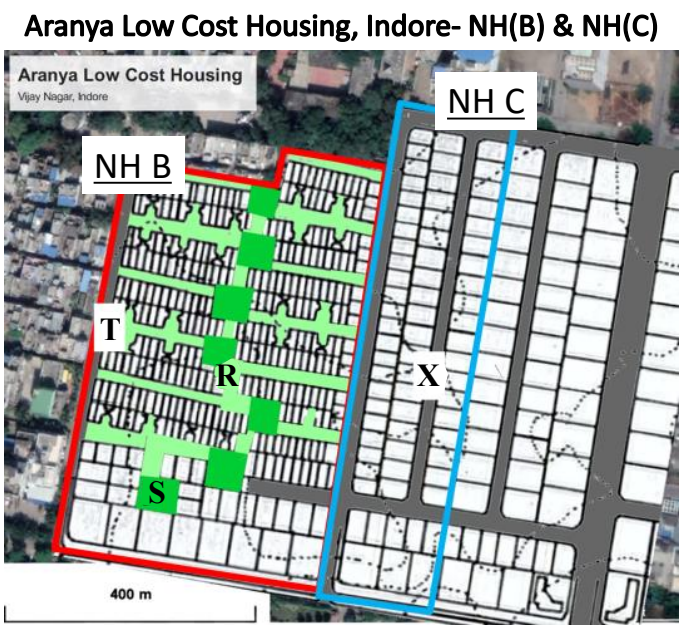

Figure 2 Open Spaces in chosen Indian neighborhoods (NH) of Jethabhai ni Pol, Ahmedabad and Aranya Low Cost Housing, Indore

\section{Analysis}

\subsection{Comparison of open spaces in Europe and India:}

It is found that that in neighbourhoods in the western counterparts, large open spaces provided with various amenities are more conducive to social interactions. In both the chosen case studies the spaces are disconnected from the buildings around them and are thus used only for their conceived functions. Neighbourhoods are provided with grey spaces in form of plazas and promenades or green spaces in form of gardens and parks. The open spaces in Indian neighbourhoods differ in their scale and function. Most are incidental spaces created by the opening of the built form onto the open space in a series of transition spaces such as otla or balcony. As in $\mathrm{NH}(\mathrm{A})$ and $\mathrm{NH}(\mathrm{B})$, these open space are extensions of the inside space of the surrounding houses and are used to live daily lives through a variety of activities such as reading the newspaper or washing clothes. Social interaction is poor in neighbourhoods where this connection is not established as seen in $\mathrm{NH}(\mathrm{C})$.

Table 3 Comparison of Neighbourhood Open Spaces in European and Indian Neighbourhoods

\begin{tabular}{|l|l|l|l|}
\hline Neighbourhood & PERCEIVED & CONCEIVED & LIVED \\
\hline $\begin{array}{l}\text { MediaCityUK; } \\
\text { U.K. } \\
\text { Nottavagen; }\end{array}$ & $\begin{array}{l}\text { The residents use the spaces } \\
\text { within their conformed } \\
\text { functions within restricted time }\end{array}$ & $\begin{array}{l}\text { Provision is made for either grey spaces in form } \\
\text { of plazas and promenades or green spaces in } \\
\text { form of gardens and parks. } \\
\text { The open spaces are well defined large expanses. }\end{array}$ & $\begin{array}{l}\text { The residents seek openness and } \\
\text { surveillance for feeling of security. } \\
\text { Protection from climate is not a big concern }\end{array}$ \\
$\begin{array}{l}\text { NH A, B \& C; } \\
\text { India }\end{array}$ & $\begin{array}{l}\text { The residents carry out their } \\
\text { daily lives in the provided space } \\
\text { as an extension to their homes }\end{array}$ & $\begin{array}{l}\text { The spaces are grey/green incidental spaces or } \\
\text { small plazas interconnected to each other and } \\
\text { small in scale as compared to those in the west }\end{array}$ & $\begin{array}{l}\text { The spaces are secured by the presence of } \\
\text { 'eyat provide shade from the sun and rain }\end{array}$ \\
\hline
\end{tabular}

\subsection{Comparative study of Indian neighbourhoods:}

The neighbourhoods are studied and compared (Table 4) in terms of perceived and lived space using a three point scale (1 Table 5). This is based on the researcher's perception.

4.2.1 $N H(A)$ : The open spaces are a product of social relationships that have developed through time helped by presence of well-articulated public space. The arrangement of spaces is responsive to the climate making them comfortable and pleasurable for the users. The private spaces of the surrounding houses extend through the transitional spaces of the otlas to the public open spaces creating a feeling of security and enhancing the sense of place.
4.2.2 $N H(B)$ : It is planned on the same lines as $\mathrm{NH}(\mathrm{A})$ and works well for social interaction. Daily chores and special functions provide ample opportunities to fraternize with neighbours[21]. The open spaces are safe and quite comfortable. The perceived space is strong but there are deficiencies in lived space due to the lower quality of experience provided to the user.

4.2.3 $N H(C)$ : The open space lacks opportunities for social interaction. It is unsupported by the built environment causing it to remain unutilized. The study shows that both perceived and lived space have been neglected while conceiving the open space here. 
Table 4 Comparison of Perceived and Lived Spaces in the selected Indian neighbourhoods

\begin{tabular}{|c|c|c|c|c|c|c|c|c|}
\hline \multirow{2}{*}{ : } & \multirow{2}{*}{\multicolumn{2}{|c|}{ Indicator }} & \multirow[b]{2}{*}{ Requirements } & \multicolumn{5}{|c|}{ Findings } \\
\hline & & & & \multicolumn{2}{|l|}{ NH A } & \multicolumn{2}{|l|}{ NH B } & NH C \\
\hline \multicolumn{9}{|c|}{ PERCEIVED SPACE } \\
\hline \multirow{3}{*}{\multicolumn{2}{|c|}{ Land use }} & & $\begin{array}{l}\text { Surrounded by land uses that contribute to social interactions } \\
\text { at all times of day }\end{array}$ & \multirow{3}{*}{$\begin{array}{l}\text { Largely residential } \\
\text { with presence of } \\
\text { institutional, } \\
\text { commercial and } \\
\text { mixed use }\end{array}$} & \multirow{3}{*}{\multicolumn{2}{|c|}{$\begin{array}{l}3 \text { Residential colony } \\
\text { has evolved into } \\
\text { mixed used }\end{array}$}} & \multirow{3}{*}{\multicolumn{2}{|c|}{ Residential area }} \\
\hline & & & $\begin{array}{l}>\text { Half surrounding land uses contribute to social interactions } \\
\text { at all times of day }\end{array}$ & & & & & \\
\hline & & & Surrounded by land uses that do not contribute to interactions & & & & & \\
\hline \multirow{9}{*}{ 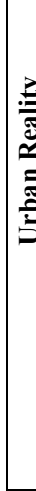 } & \multirow[t]{3}{*}{ Building height } & 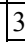 & Provides shade and sense of enclosure & \multirow{3}{*}{\multicolumn{2}{|c|}{$\begin{array}{l}\text { Two to four floor } \\
\text { buildings provide } \\
\text { shade and sense of } \\
\text { enclosure }\end{array}$}} & & \multirow{3}{*}{\multicolumn{2}{|c|}{$3 \mid \begin{array}{l}\text { Two storey } \\
\text { houses with } \\
\text { compound wall } \\
\text { provides no } \\
\text { shade }\end{array}$}} \\
\hline & & & $\begin{array}{l}\text { Provides shade to only periphery and/or lacks sense of } \\
\text { enclosure }\end{array}$ & & & & & \\
\hline & & 1 & Does not provide shade nor sense of enclosure & & & & & \\
\hline & \multirow[t]{3}{*}{ Building type } & & $\begin{array}{l}\text { Presence of transition spaces such as balconies \& porches that } \\
\text { connects to open space }\end{array}$ & \multirow{3}{*}{\multicolumn{2}{|c|}{\begin{tabular}{|l|} 
Incidental open and \\
semi-open spaces \\
present along street, \\
including the otla -the \\
entrance of the house
\end{tabular}}} & \multirow{3}{*}{$3 \begin{array}{l}\text { Incidental spaces } \\
\text { along inner streets } \\
\& \text { platforms in front } \\
\text { of houses extending } \\
\text { into the chowk. }\end{array}$} & & \begin{tabular}{l|} 
Compound \\
walls prevent
\end{tabular} \\
\hline & & 2 & Absence of same level transition spaces & & & & & connection to \\
\hline & & 1 & Absence of connections to OS & & & & & \\
\hline & $\begin{array}{l}\text { Surface } \\
\text { materials }\end{array}$ & 3 & $\begin{array}{l}\text { Well maintained flooring conducive to walking and regulated } \\
\text { speed of vehicular traffic }\end{array}$ & $\begin{array}{l}\text { Kota stone road } \\
\text { surface regulates }\end{array}$ & & $\begin{array}{l}\text { Granite cobble stone } \\
\text { surface discourage }\end{array}$ & & $\begin{array}{l}\text { Tarred road not } \\
\text { meant for }\end{array}$ \\
\hline & & 2 & Unmaintained or unsegregated pedestrian space & speed and is & 3 & vehicles. & & pedestrian use \\
\hline & & & $\begin{array}{l}\text { Rough/unmaintained flooring difficult to walk on and no } \\
\text { segregation from vehicular traffic }\end{array}$ & $\begin{array}{l}\text { comfortable for } \\
\text { walking }\end{array}$ & & & & \\
\hline & Intended use & & Inclusive to all groups of people & Used by all & & Used by all & & Not used \\
\hline & & & Restricted to certain group of people & & 3 & & 哣 & \\
\hline & & 1 & Intended only for commercial/ transport use & & & & & \\
\hline. & User activity & 3 & Used for variety of activities throughout the day & Commercial and & & & & Vehicular \\
\hline 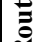 & & 2 & Restricted to less than two activities/ deserted at certain times & hold activities, & & household activities, & & traffic and \\
\hline & & 1 & Used only as passage between two points & & & & & \\
\hline 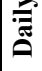 & Accessibility & & $\begin{array}{l}\text { Pedestrian only space accessible within } 10 \text { min walk from all } \\
\text { points in NH }\end{array}$ & $\begin{array}{l}\text { Easily accessible. } \\
\text { Inner chowks are }\end{array}$ & & $\begin{array}{l}\text { Dead end streets } \\
\text { provide pedestrian }\end{array}$ & & $\begin{array}{l}\text { No traffic } \\
\text { segregation }\end{array}$ \\
\hline & & & $\begin{array}{l}\text { Pedestrian friendly with light segregated traffic accessible in } \\
<10 \text { min walk from all points }\end{array}$ & & & $\begin{array}{l}\text { only spaces. } \\
\text { Vehicular traffic is }\end{array}$ & & \\
\hline & & & Heavy trafficked space not used by pedestrians & footpaths along street. & & separated in chowks & & \\
\hline & & & PACE & & & & & \\
\hline & Protection & & Closed to the vehicular traffic & Slow moving traffic & & Dead end inner & & High moving \\
\hline & against traffic & 2 & Has slow moving traffic and predominantly pedestrian traffic & on streets and & & streets restrict & & \\
\hline & \& accidents & & $\begin{array}{l}\text { Has high moving vehicular traffic that dominates pedestrian } \\
\text { traffic }\end{array}$ & $\begin{array}{l}\text { pedestrian only inner } \\
\text { chowks }\end{array}$ & & $\begin{array}{l}\text { traffic. Segregated } \\
\text { traffic in chowks }\end{array}$ & & \\
\hline : & Protection & 3 & All parts within sight of eyes on the street & Balconies allow & & Presence of unbuilt & & Unsupervised at \\
\hline & against crime \& & 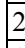 & Presence of periphery spaces which are not within observation & residents to keep & & spaces leave blind & & \\
\hline$\stackrel{2}{2}$ & violence & & Remains unsupervised at all times & watch from above & & & & \\
\hline & Protection & 3 & Places to hide both from rain and sun & Otlas provide & & Low height houses & & No protection \\
\hline & against un- & 2 & Places only to hide from rain but no protection from sun & protection from rain & & leave larger chowks & & from rain and \\
\hline & $\begin{array}{l}\text { pleasant sense } \\
\text { experiences }\end{array}$ & & No places to hide both from rain and sun & $\begin{array}{l}\text { and projecting } \\
\text { balconies give shade }\end{array}$ & & & & \\
\hline & Possibilities for & 3 & Maintained surface for walking distinct from vehicular traffic & Inner paths leading to & & Chowks divided & & No pedestrian \\
\hline & walking & 2 & Presence of uneven surfaces and intrusion by vehicular traffic & & & into concreted & & \\
\hline & & 1 & No distinct space for pedestrians & & & $\begin{array}{l}\text { vehicular area \& } \\
\text { rest in terracotta } \\
\text { tiles. }\end{array}$ & & \\
\hline & Possibilities for & 3 & Provides interests and opportunities to stand and stay & Presence of & & Presence of & & No possibility \\
\hline & standing & 2 & Provides standing spaces but no interest to make people stay & transitional spac & & transitional spaces & & \\
\hline & & & Creates only possibilities for walking & $\begin{array}{l}\text { pedestrian only } \\
\text { chowks }\end{array}$ & & $\begin{array}{l}\text { and pedestrian only } \\
\text { area }\end{array}$ & & \\
\hline & Possibilities & 3 & Various possibilities to sit comfortably & Incidental seating & & Work platforms in & & No possibility \\
\hline 党 & for sitting & 2 & Sitting spaces present but not comfortable & ong & & chov & & \\
\hline $\bar{\Xi}$ & & 1 & No possibilities for sitting & the & & street & & \\
\hline U & Possibilities to & 3 & Well lit & Certain dark spots on & & Presence of unlit & & Poor lighting \\
\hline & & & Lit, however the lighting creates an effect of a glare & inner paths & & spots at centre of & & \\
\hline & & & Not lit & & & & & \\
\hline & Possibilities & 3 & Affected by noise $<60 \mathrm{~dB}$ & Restricted traffic & & & & Traffic \\
\hline & & 2 & Affected by noise $60-80 \mathrm{~dB}$ & keeps noise down & & keeps noise down & & loud ne \\
\hline & & & Affected by noise $>80 \mathrm{~dB}$ & & & & & \\
\hline & Possibilities for & 3 & Provides a permanent possibility for playing or other activities & Safe areas for children & & Safe areas for & & No safe area \\
\hline & play/activities & & Provides a temporary possibility for playing or other activities & & & o play & & en to \\
\hline & & & Does not provide any possibility for playing or other activities & & & & & \\
\hline
\end{tabular}




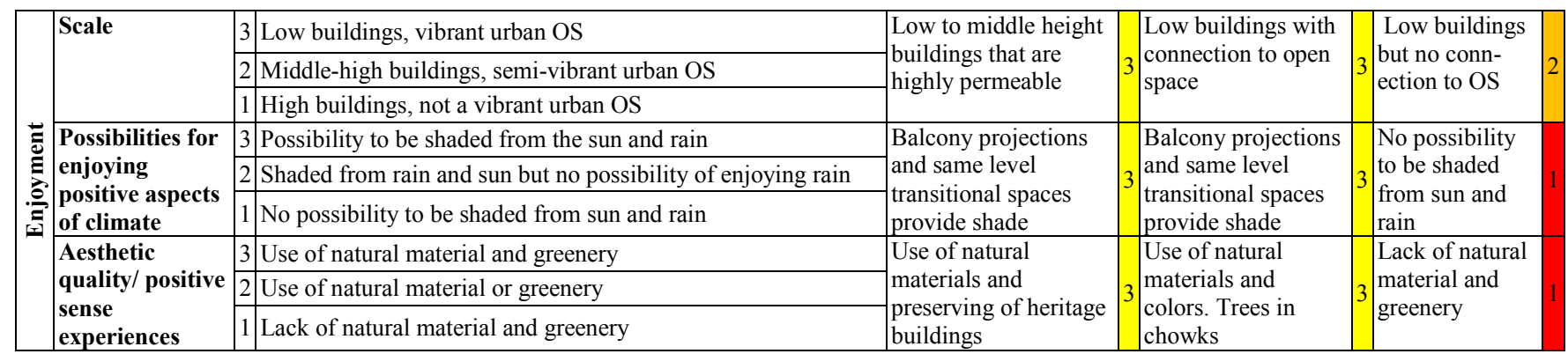

${ }^{1}$ Table 5 Scale description for observed data

\begin{tabular}{|c|c|c|c|}
\hline 3 & 2 & & 1 \\
\hline Good & Average & & Poor \\
\hline
\end{tabular}

In Table 4 the identified criteria (Table 1) are adapted for Indian conditions. From the understanding gained in Table 4 it is found that users in India lay more emphasis on i) climate protection, ii) connection of surrounding houses to the open space, and iii) security through eyes on street, These indicators are thus included.

Values for perceived and lived space generated in Table 4 are compared in Fig. 3. This provides an understanding of the suitability of the open spaces in the neighbourhoods for social cohesion.

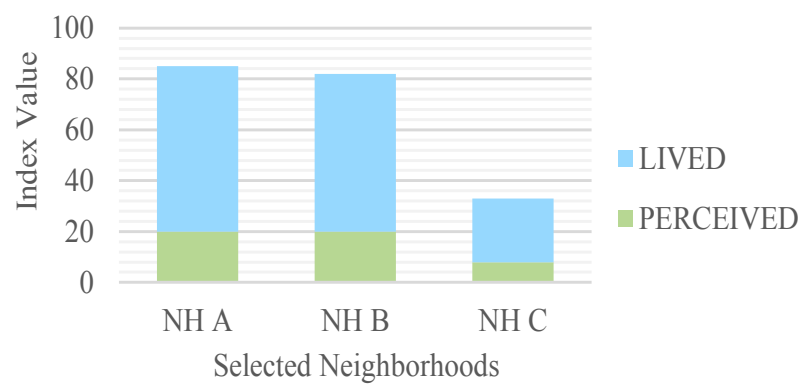

Fig. 3 Comparative index values of NH (A), (B) \& (C)

\section{Conclusion}

Through a comparison of case studies it is understood that neighbourhood open spaces are produced by forces termed by Henri Lefebvre as perceived, conceived and lived.

The neighbourhood open spaces seen in the case studies from U.K. and Norway differ from those seen in Indian neighbourhoods in all three dimensions of space. The comparison of the Indian neighbourhood open spaces reveals that the Ahmedabad pol $\mathrm{NH}(\mathrm{A})$ provides the most suitable spaces for social cohesion. The first neighbourhood considered in Aranya NH(B) also provides conducive open spaces but the second neighbourhood $\mathrm{NH}(\mathrm{C})$ fairs poorly. This concludes that the neighbourhood open space needs to be planned, designed and constructed in coordination to provide positive experiences to the users.

The Unitary Theory is used to develop a framework for the study of neighbourhood spaces. The criteria for study are derived from case studies and indicators are identified for each. A three point scale is developed for the measurement of these indicators. Smart Cities provide opportunity for better data collection and people's participation through technology advances. This can be used to produce neighbourhood open spaces through proper coordination between the three spaces that will create opportunities for social interactions.

\section{References}

[1] R. Forrest and A. Kearns, "Social Cohesion, Social Capital and the Neighbourhood," Urban Studies, vol. 38, no. 12, pp. 2125-2143, 2001.

[2] A. M. Salama and R. Y. Gharib, "A Perceptual Approach for Investigating Urban Space Diversity in the City of," Open House International, vol. 37, no. 2, 2012.

[3] A. Legeby and L. Marcus, "Does the Urban Structure of Swedish Cities Inhibit the Sharing of Public Space?," Built Environment, vol. 37, no. 2, pp. 155-169, 2011.

[4] I. Bibeva, "Public space and its role for segregation, identity and everyday life.," Stockholm University, Stockholm, 2012.

[5] Y. Chen, T. Liu, X. Xie, and B. G. Marusic, "What Attracts People to Visit Community Open Spaces? A Case Study of the Overseas Chinese Town Community in Shenzhen, China," International Journal of Enironmental Research and Public Health, vol. 13, no. 644, pp. 1-17, 2016.

[6] C. Nieuwenhuis, "New Urbanism," Provo \# 9, 1966.

[7] M. Jenks and N. Dempsey, "Defining the neighbourhood: Challenges for empirical research," The Town planning review vol. 78, no. 2, pp. 153$177,2007$.

[8] A. Nochian, O. M. Tahir, S. Maulan, and M. Rakhshanderoo, "A Comprehensive Public Open Space Categorization Using Classification System for Sustainable Development of Public Open Spaces," Alam Cipta, pp. 29-40, 2015.

[9] M. Gottdiener, The Social Production of Urban SPace. Austin: University of Texas Press, 1985.

[10] "Urban and Regional Development Plans Formulation and Implementation (URDPFI) Guidelines Vol 1," GOI MoUD, 2015.

[11] B. W. Stanley and B. L. Stark, "Urban Open Spaces in Historical Perspective: A Transdisciplinary Typology and Analysis," Urban Geography, vol. 33, no. 8, pp. 1089-1117, 2012.

[12] S. Raman and N. Dempsey, "Cultural Diversity and Spatial Structure in the Indian Urban Context," Journal of Urban Design, vol. 17, no. 3, pp. 425-447, 2012.

[13] D. Gri, "Social cohension created through Public Spaces in Toronto Neighbourhoods," Technical Transactions, no. 6, pp. 1-4, 2010.

[14] A. Giddens, The Constitution of Society. Outline of the Theory of Structuration. Cambridge: Polity Press, 1984.

[15] B. Hillier and J. Hanson, The Social Logic of Space. Cambridge: Cambridge University Press, 1984.

[16] H. Lefebvre, The Production of Space. Malden, USA: Blackwell Publishing, 1974

[17] J. Weinert, "Making Sense of Lefebvre's "The Production of Space"," Ethnology in Halle, Accessed on: August[Online]. Available: https://blog.ethnologie.uni-halle.de/2015/08/\%E2\%80\%A8theproduction-of-space/

[18] R. M. Chitrakar, "Transformation of Public Space in Contemporary Urban Neighbourhoods of Kathmandu Valley, Nepal: An Investigation of Changing Provision, Use and Meaning," Queensland University of Technology, Queensland, 2015.

[19] A. Górska and A. Materna, "What is the value of BREEAM Communities?," Aalborg University, Aalborg, 2017.

[20] L. A. Griffith, "Structuring Neighbourhood Space: An Investigation into the Production of Neighbourhood Space as Planned, Practiced, and Lived in Post-Industrial Norway," University of Stavanger, Stavanger, Norway, 2013.

[21] A. Parashar, "Living Street-Aspects of Public Space in Jethabhai ni Pol \& Aranya," The University of British Colombia, Vancouver, 2005.

[22] S. Sejpal, "Theory and City Form: The Case of Ahmedabad," Massachusetts Institute of Technology, Ahmedabad, 1987. 